\title{
ПРАВОВЕ РЕГУЛЮВАННЯ ДІЯЛЬНОСТІ ЮРИДИЧНИХ ВІДДІЛІВ ТА МІСЦЕ У НЬОМУ АДМІНІСТРАТИВНОГО ЗАКОНОДАВСТВА
}

\author{
КРИВКО Ольга Олегівна - здобувач Інституту права та суспільних відносин \\ Відкритого міжнародного університету розвитку людини «Україна»
}

DOI:10.32782/LAW.2020.1.7

УДК: 342.95 (477)

Надається характеристика системі пра-
вового регулювання діяльності юридичних
відділів в Украӥні. Акцентовано увагу, шо пра-
вове регулювання діяльності юридичних від-
ділів виражається у нормах права, які закрі-
плюються не тільки в законах, але й у інших
нормативно-правових актах різної ієрархіч-
ної підпорядкованості. Наведено зміст кож-
ного з них для з'ясування місия в їх системі
правових документів адміністративної галузі
права.

Констатовано, що норми Основного Закону є базою правового регулювання суспільних відносин у нашій державі в иілому. Вони бормують підгрунтя правового впливу, а також принципи правової реальності всієі держави. Дані приниипи є основоположними для всіх без винятку категорій та інститутів, у тому числі і у сфері правового регулювання діяльності юридичних відділів.

Узагальнено, що виходячи із змісту більшості проаналізованих у статті нормативних документів, можна зробити висновок, що велика група із загального числа останніх належить саме до адміністративного законодавства. Адже їх норми регламентують суспільні відносини, пов'язані із структурною належністю юридичних відділів у системі державного управління, взаємодією даних відділів з органами державної влади, реалізачією ними своїх прав, обов'язків та функиій, а, крім того, закріплюють своїми нормами адміністративно-правовий статус останніх. У зв'язку із иим, адміністративне законодавство можна вважати домінуючим у системі правового регулювання діяльності юридичних відділів в Украӥні.

Ключові слова: правове регулювання, нормативно-правовий акт, юридичні відділи, адміністративне законодавство.

\section{Постановка проблеми}

Конституція України проголошуе панування на території держави принципу верховенства права. Це означає, що за своїм змістом право є основним регулятором суспільних відносин у правовій системі. Не є винятком у наведеному контексті і правові відносини, які виникають у галузі діяльності юридичних відділів. Разом із тим слід відмітити, що зазначеній галузі притаманна власна специфічна система правового регулювання, що включає в себе велику кількість норм права, які знаходять своє об'єктивне відображення у низці нормативно-правових актів різної юридичної сили. Окреме місце в зазначеній системі відведено адміністративному законодавству, роль якого в аспекті правового регулювання діяльності юридичних відділів і буде досліджено надалі у представленій науковій праці.

\section{Стан дослідження}

Проблема правового регулювання діяльності різних органів державної влади, в тому числі і їх структурних підрозділів, не $\epsilon$ новою. Їй неодноразово у своїх наукових дослідженнях приділяли увагу: О.О. Акімов, Я.М. Буздуган, І.П. Голосні- 
ченко, І.В. Міщенко, В.С. Нерсесянц, О.М. Музичук, Н.М. Оніщенко, Ю.В. Слабунова, В.В. Сокуренко, С.Г. Стеценко, Т.В. Терещенко, А.І. Якимів, С.М. Яровий та багато інших. Втім, незважаючи на чималу кількості наукових здобутків, у юридичній літературі відсутні комплексні дослідження, присвячені правовому регулюванню діяльності юридичних відділів.

Саме тому метою статті є: надати характеристику правовому регулюванню діяльності юридичних відділів та визначити місце у ньому адміністративного законодавства.

\section{Виклад основного матеріалу}

Науковці мають різні погляди на зміст категорії «правове регулювання» та в кожному окремому випадку пропонують власний перелік особливостей, якими зазначене явище характеризується. Не можна не погодитись із переконанням більшості вчених про те, що правове регулювання виражає вплив на суспільні відносини. Дійсно, саме через зазначену категорію проявляються особливості юридичного упорядкування соціуму за рахунок права, як основного регулятора суспільних відносин. На нашу думку, правове регулювання діяльності юридичних відділів виражається у нормах права, які закріплюються не тільки в законах, але й інших нормативно-правових актах різної ієрархічної підпорядкованості. Наведемо зміст кожного 3 них для 3'ясування місця в їх системі правових документів адміністративної галузі права.

Першим нормативним джерелом правового регулювання діяльності юридичних відділів є Конституція України. Остання є єдиним, що володіє особливими юридичними властивостями, нормативно-правовим актом, за допомогою якого український народ виражає свою суверенну волю, установлює основні принципи устрою суспільства і держави, визначає систему і структуру державної влади і місцевого самоврядування, механізми реалізації державно-владних повноважень, основи правового статусу особи, територіальний устрій держави [1;2, с.117]. Важливість Конституції України наділяє їі рядом характерних ознак. По-перше, Конституція за своєю сутністю є Основним Законом («lex fundamentales»), що виражає волю Українського народу і політику держави; по-друге, за змістом Конституція має вищу юридичну силу; по-третє, норми Конституції є нормами прямої дії; по-четверте, Конституція приймається і вводиться в дію відповідно до передбаченої законом спеціальної процедури. Спеціальна процедура передбачена і щодо внесення змін і доповнень до Основного Закону. По-п'яте, чинне законодавство передбачає спеціальний механізм правового захисту, гарантування Конституції [3, с.10].

Таким чином, норми Основного закону є базою правового регулювання суспільних відносин у нашій державі в цілому. Вони формують підгрунтя правового впливу, а також принципи правової реальності всієї держави. Дані принципи є основоположними для всіх без виключення категорій та інститутів, зокрема, правового регулювання діяльності юридичних відділів. Іншими словами, Основний закон формує легальний порядок у державі. Так, до прикладу, відповідно до статті 19 Конституції правовий порядок в Україні грунтується на засадах, відповідно до яких ніхто не може бути примушений робити те, що не передбачено законодавством. Органи державної влади та органи місцевого самоврядування, ї посадові особи зобов'язані діяти лише на підставі, в межах повноважень та у спосіб, що передбачені Конституцією та законами України. Крім того, в Конституції вказується, що Україна є суверенна і незалежна, демократична, соціальна, правова держава. Аюдина, ії життя і здоров'я, честь і гідність, недоторканність і безпека визнаються в Україні найвищою соціальною цінністю. Права і свободи людини та їх гарантії визначають зміст і спрямованість діяльності держави. Держава відповідає перед людиною за свою діяльність. Утвердження і забезпечення прав і свобод людини є головним обов'язком держави [4].

У системі правового регулювання діяльності юридичних відділів в Україні варто виділити Закон України «Про центральні органи виконавчої влади» від 17.03.2011 


\section{Адміністративне право}

№3166-VI. Зазначений закон безпосередньо не регламентуе особливості роботи вказаних суб'єктів, водночас, він формує засади правового статусу органів влади та підпорядкованих їм установ, підприємств та організацій, у складі яких юридичні відділи працюють, у зв'язку із чим не можна залишити положення даного нормативноправового акта поза увагою. Так, відповідно до норм Закону систему центральних органів виконавчої влади складають міністерства України та інші центральні органи виконавчої влади. Система центральних органів виконавчої влади є складовою системи органів виконавчої влади, вищим органом якої є Кабінет Міністрів України. Міністерства забезпечують формування та реалізують державну політику в одній чи декількох сферах, інші центральні органи виконавчої влади виконують окремі функції з реалізації державної політики. Повноваження міністерств, інших центральних органів виконавчої влади поширюються на всю територію держави. Діяльність міністерств та інших центральних органів виконавчої влади грунтується на принципах верховенства права, забезпечення дотримання прав і свобод людини і громадянина, безперервності, законності, забезпечення єдності державної політики, відкритості та прозорості, відповідальності. Міністерства діють за принципом єдиноначальності. Інші центральні органи виконавчої влади діють за принципом єдиноначальності, якщо інше не передбачено законом. 3. Підприємства, установи та організації, що належать до сфери управління міністерств, інших центральних органів виконавчої влади, не можуть здійснювати владні повноваження, крім випадків, визначених законом [5].

У тому ж аспекті необхідним до виділення є Закон України «Про Кабінет Міністрів України» від 27.02.2014 №794-VII. У положеннях акта вказується, що Кабінет Міністрів України (далі - КМУ) є вищим органом у системі органів виконавчої влади. Кабінет Міністрів України здійснює виконавчу владу безпосередньо та через міністерства, інші центральні органи виконавчої влади, Раду міністрів Автономної
Республіки Крим та місцеві державні адміністрації, спрямовує, координує та контролюе діяльність цих органів. Одним із ключових завдань, яке ставиться перед Кабінетом Міністрів України, є спрямування та координація роботи міністерств, інших органів виконавчої влади, здійснення контролю за їх діяльністю, у тому числі в аспекті функціонування юридичних відділів [6].

Важливе місце у механізмі правового регулювання діяльності юридичних відділів займають підзаконні нормативно-правові акти, зокрема, акти КМУ - Постанова Кабінету Міністрів України «Про затвердження Загального положення про юридичну службу міністерства, іншого органу виконавчої влади, державного підприємства, установи та організації» від 26.11.2008 №1040. Затверджене нею Положення регулює питання діяльності юридичної служби міністерства, іншого центрального органу виконавчої влади та їх територіальних органів, місцевих держадміністрацій, а також державного підприємства, установи та організації. До того ж у Положенні зазначається, що юридична служба у своїй діяльності керується Конституцією та законами України, указами Президента України і постановами Верховної Ради України, прийнятими відповідно до Конституції та законів України, актами Кабінету Міністрів України, міжнародними договорами України, цим Положенням, а також іншими нормативно-правовими актами. 3 питань організації та проведення правової роботи юридична служба керується актами Мін'юсту [7].

Звернути увагу також варто на положення Постанови Кабінету Міністрів України «Про вдосконалення організації правової роботи в міністерствах, інших центральних органах виконавчої влади» від 14.12.2001 №1693. Метою даного документа визначено забезпечення законності в роботі міністерств, інших центральних органів виконавчої влади, запобігання порушенню прав і законних інтересів громадян, підприємств, установ, організацій, залучення висококваліфікованих фахівців до роботи в юридичних службах центральних органів 
виконавчої влади, активізації та вдосконалення правової роботи, посилення контролю за цією роботою Кабінету Міністрів України. Задля реалізації наведеної цілі міністерства, інші центральні органи виконавчої влади було зобов' язано: забезпечити належний рівень правової роботи у відповідних сферах державного управління, у тому числі методичного керівництва правовою роботою на підприємствах, в установах, організаціях, що належать до сфери їх управління, вжити заходів до впровадження ефективних форм і методів діяльності юридичних служб та до реалізації рекомендацій органів юстиції; здійснювати в межах своєї компетенції постійний перегляд нормативно-правових актів з метою приведення їх у відповідність 3 Конституцією та законами України, іншими актами законодавства, усунення множинності, скасування застарілих актів і таких, що не відповідають новим умовам соціально-економічного розвитку України; забезпечити обов'язкове узгодження 3 юридичною службою проектів нормативно-правових актів, відповідальним за розроблення яких є центральний орган виконавчої влади; вжити заходів до підвищення ефективності роботи юридичних служб та укомплектування їх висококваліфікованими фахівцями; забезпечувати участь працівників юридичних служб у роботі семінарів, інших заходах, які проводяться Міністерством юстиції; створити належні умови для роботи юридичних служб, зокрема забезпечити їх окремими приміщеннями, необхідним обладнанням та нормативними актами, іншою правовою інформацією тощо [8].

Значна кількість правових норм, які регулюють правові відносини в галузі діяльності юридичних служб, міститься в актах Міністерства юстиції України. Наприклад, у Наказі «Про затвердження Примірної програми проведення перевірок стану правової роботи та систематизації законодавства в міністерствах, інших органах виконавчої влади, на державних підприємствах, в установах, організаціях та державних господарських об'єднаннях» від 11.03.2013 №403/5 чітко визначаються зміст правової роботи. Відповідно до нормативного тлу- мачення - це діяльність юридичної служби або юрисконсульта відповідної категорії, що виконує функції юридичної служби, щодо забезпечення правильного застосування, неухильного дотримання та запобігання невиконанню вимог чинного законодавства об'єктом перевірки, його керівниками та працівниками під час виконання покладених на них завдань і функціональних обов'язків. Крім того в наказі зазначається, які саме органи Міністерства юстиції України здійснюють перевірку правової роботи та систематизації законодавства. Наприклад, з питань правових робіт у міністерствах, інших центральних органах виконавчої влади перевірку провадить безпосередньо Мін'юст, у свою чергу, у місцевих органах виконавчої влади (районних, районних у містах Києві та Севастополі державних адміністраціях та їх структурних підрозділах), територіальних органах центральних органів виконавчої влади, державних господарських об'єднаннях, на державних підприємствах, в установах та організаціях - районні, районні у містах, міські (міст обласного значення), міськрайонні, міжрайонні управління юстиції [9]. До джерел правового регулювання діяльності юридичних відділів в Україні також відноситься Наказ Міністерства юстиції України «Про затвердження Порядку погодження у Міністерстві юстиції України призначення на посаду керівників юридичних служб міністерств, інших центральних органів виконавчої влади» від 29.03.2017 №1042/5. Порядок застосовується під час розгляду питань щодо погодження призначення на посаду керівників юридичних служб міністерств, інших центральних органів виконавчої влади. Також у документі вказується, що подання щодо погодження у Міністерстві юстиції України призначення претендента на посаду керівника юридичної служби міністерства вноситься керівником відповідного міністерства Міністру юстиції України. Подання складається у довільній формі із зазначенням прізвища, імені та по батькові претендента; його дати народження; громадянства; займаної посади; посади, на яку претендент рекомендується; досвіду роботи на посадах державної 


\section{Адміністративне право}

служби категорії «Б» чи «В», або досвіду служби в органах місцевого самоврядування, або досвіду роботи на керівних посадах підприємств, установ та організацій незалежно від форми власності [10].

Окреме коло питань правового регулювання діяльності юридичних відділів регламентується актами Президента нашої держави. Так, відповідно до Указу Президента України «Про деякі заходи щодо зміцнення юридичних служб державних органів» від 30.06.2006 №272/2000, з метою підвищення рівня правового забезпечення діяльності органів державної влади та інших державних органів, поліпшення якості підготовки проєктів нормативноправових актів, стимулювання залучення до зазначеної діяльності висококваліфікованих фахівців: керівникам державних органів (апаратів цих органів) рекомендовано установити, що юридичні служби входять до складу зазначених органів (апаратів цих органів) як самостійні підрозділи і підпорядковуються безпосередньо керівникам цих органів (апаратів цих органів) [11].

Велика кількість організаційних питань роботи юридичних відділів регламентована положеннями відомчого законодавства, норми якого направлено на регулювання суспільних відносин, що виникають у рамках роботи юридичних служб конкретних органів влади. До числа подібних нормативних документів можна віднести: Наказ Міністерства оборони України Наказом «Положення про Юридичний департамент Міністерства оборони України» від 16.05.2016 №259; Наказ ДСНС України «Про затвердження Методичних рекомендацій щодо організації правової роботи в головних управліннях (управлінь) ДСНС України в АР Крим, областях, мм. Києві та Севастополі, на підприємствах, в установах, організаціях і спеціальних формуваннях сфери управління ДСНС України» від 25.04.2014 № 186; Наказ Головного управління Національної поліції в Харківській області «Про затвердження Положення про відділ правового забезпечення ГУНП в Харківській області» від 02.02.2017 №150; Наказ Міністерства внутрішніх справ України «Про затвердження Положення про
Департамент юридичного забезпечення Міністерства внутрішніх справ України» від 15.03.2018 №206 і таке інше [12; 13; 14].

\section{Висновок}

Таким чином, проведений у роботі аналіз показав, що правове регулювання діяльності юридичних відділів на сьогодні засновується на великій кількості юридичних норм, що містяться в актах різної галузевої приналежності. Водночас, виходячи із змісту більшості представлених нормативних документів можна зробити висновок, що велика група із загального числа останніх відноситься саме до адміністративного права. Адже їх норми регламентують суспільні відносини пов'язані із структурною належністю юридичних відділів у системі державного управління, взаємодією даних відділів 3 органами державної влади, реалізацією ними своїх прав, обов'язків та функцій, а, крім того, закріплюють своїми нормами адміністративно-правовий статус останніх.У зв'язку із цим, адміністративне законодавство можна вважати домінуючим у системі правового регулювання діяльності юридичних відділів в Україні.

\section{Лiтература}

1. Тодика Ю.М. Конституція України-Основний Закон держави і суспільства: Навч. посібник. Х.: Факт, 2001.

2. Болдирев С.В. Організаційно-правові питання місцевого самоврядування в Україні: дисертація / С.В. Болдирев // Харків: Національна юридична академія України імені Ярослава Мудрого. 2003. 228 с.

3. Чистоколяний Я.В. Конституційно-правові норми в Україні: дисертація /Я.В. Чистоколяний // Київ: Національна академія наук України. 2005. 20 с.

4. Конституція України: закон від 28.06.1996 №254к/96-ВР // Офіційний вісник України. 2010. №72/1. ст.2598.

5. Про центральні органи виконавчої влади: закон від 17.03.2011 №3166-VI // Відомості Верховної Ради України. 2011. №38. ст.385.

6. Про Кабінет Міністрів України: закон від 27.02.2014 №794-VII // Відомості Верховної Ради України. 2014. №13. ст.222. 
7. Про затвердження Загального положення про юридичну службу міністерства, іншого органу виконавчої влади, державного підприємства, установи та організації: постанова, положення від 26.11.2008 №1040 // Офіційний вісник України. 2008. №93. ст.3068.

8. Про вдосконалення організації правової роботи в міністерствах, інших центральних органах виконавчої влади: постанова від 14.12.2001 №1693 // Офіційний веб-портал Міністерства юстиції України. [Електронний ресурс]. Режим доступу: https://minjust.gov.ua/m/postanova-kabinetuministriv-ukraini-vid-14-grudnya-2001roku-1693-pro-vdoskonalennya-organizatsiipravovoi-roboti-v-ministerstvah-inshihtsentralnih-organah-vikonavchoi-vladi.

9. Про затвердження Примірної програми проведення перевірок стану правової роботи та систематизації законодавства в міністерствах, інших органах виконавчої влади, на державних підприємствах, в установах, організаціях та державних господарських об’єднаннях: наказ від 11.03.2013 №403/5 // Офіційний веб-портал Міністерства юстиції України. - [Електронний ресурс]. - Режим доступу: https://minjust.gov. $\mathrm{ua} / \mathrm{m} / \mathrm{str} 43450$.

10. Про затвердження Порядку погодження у Міністерстві юстиції України призначення на посаду керівників юридичних служб міністерств, інших центральних органів виконавчої влади: наказ від 29.03.2017 № 1042/5 // Офіційний веб-портал Міністерства юстиції України. [Електронний ресурс]. - Режим доступу: https:/ minjust.gov.ua/m/nakaz-ministerstva-yustitsiiukraini-vid-29-bereznya-2017-roku-10425- pro-zatverdjennya-poryadku-pogodjennya-uministerstvi-yustitsii-ukraini-priznachennyana-posadu-kerivnikiv-yuridichnih-slujbministerstv-inshih-tsentralnih-organivvikonavchoi-vladi-zaree.

11. Про деякі заходи щодо зміцнення юридичних служб державних органів: указ від 30.03.2006 №272/2006 // Офіційний веб-портал Міністерства юстиції України. [Електронний ресурс]. Режим доступу: https://minjust.gov.ua/m/ukaz-prezidentaukraini-vid-11-grudnya-2001-roku-1207pro-deyaki-zahodi-schodo-zmitsnennyayuridichnih-slujb-derjavnih-organiv.

12. Про затвердження Положення про юридичну службу Збройних Сил України: Наказ начальника Генерального штабу Головнокомандувача Збройних Сил України від 7 грудня 2005 року № 202.

13. Функції Департаменту юридичного забезпечення: витяг з Положення про Департамент юридичного забезпечення Міністерства внутрішніх справ України, затвердженого наказом МВС від 15 жовтня 2014 року № 1075 // [Електронний ресурс]. Режим доступу: http://mvs.gov.ua/ ua/structure/Departament-yuridichnogozabezpechennya.htm/.

14. Про затвердження Методичних рекомендацій щодо організації правової роботи в головних управліннях (управлінь) ДСНС України в АР Крим, областях,мм. Києві та Севастополі, на підприємствах, в установах, організаціях і спеціальних формуваннях сфери управління ДСНС України: наказ від 25.04.2014 № 186 // Офіційний веб-портал ДСНС України. [Електронний ресурс]. Режим доступу: https:// www.dsns.gov.ua/ua/YUridichne-upravlinnyadocs.html. 